\title{
Determination of Polychlorinated Biphenyls in Seawater using Headspace Solid-Phase Microextraction Coupled with Gas Chromatography-Mass Spectrometry with the Aid of Experimental Design
}

\author{
Xingliang Song, ${ }^{*, a, b, \#}$ Jinhua Li, ${ }^{b, \#}$ Lingxin Chen, ${ }^{*, b}$ Zongwei Cai, ${ }^{c}$ Chunyang Liao, ${ }^{b}$ \\ Hailong Peng ${ }^{d}$ and Hua Xiong ${ }^{d}$ \\ ${ }^{a}$ Department of Chemistry, Linyi University, Linyi 276005, P. R. China \\ ${ }^{b}$ Key Laboratory of Coastal Zone Environmental Processes, CAS, Shandong Provincial Key Laboratory of Coastal \\ Zone Environmental Processes, Yantai Institute of Coastal Zone Research, Chinese Academy of Sciences, \\ Yantai 264003, P. R. China \\ ${ }^{c}$ Department of Chemistry, Hong Kong Baptist University, Hong Kong SAR, P. R. China \\ ${ }^{d}$ State Key Laboratory of Food Science and Technology, Nanchang University, Nanchang 330047, P. R. China
}

\begin{abstract}
Uma abordagem de pré-tratamento simples e confiável em cromatografia gasosa acoplada à espectrometria de massa (GC-MS) foi desenvolvida para a limpeza simultânea da água do mar e concentração de bifenilas policloradas (PCBs), com 1 a 8 átomos de cloro, baseada na combinação da oxidação de $\mathrm{KMnO}_{4}$ com amostragem de headspace e microextração em fase sólida (SPME). Os fatores que afetam o processo de extração foram estudados usando uma abordagem multivariada. Sob condições ótimas, tais como fibra de PDMS com $7 \mu \mathrm{m}, 78{ }^{\circ} \mathrm{C}$ de temperatura de extração, 33 min de tempo de extração e $8 \mathrm{~mL}$ de volume, os limites de detecção do método variaram entre 0,3 e 7,5 ng L ${ }^{-1}$ e os valores de precisão variaram entre 3,9 e 9,9\%, para um nível de fortificação de $0,05 \mu \mathrm{g} \mathrm{L}{ }^{-1}$ de PCBs. Ácidos húmicos da água do mar exibiram efeitos negativos marcantes; as recuperações de PCBs foram significativamente melhoradas, especialmente para os mais lipofílicos, CB171 e CB201, de $35 \%$ e $49 \%$ para $78 \%$ e $89 \%$, respectivamente, após o pré-tratamento das amostras da água do mar com $\mathrm{KMnO}_{4} \mathrm{em} \mathrm{pH} \mathrm{6.} \mathrm{O} \mathrm{método} \mathrm{desenvolvido} \mathrm{mostrou-se} \mathrm{simples,}$ rápido, confiável e aplicável para a determinação de diferentes PCBs em água do mar contendo grandes quantidades de substâncias húmicas.
\end{abstract}

A simple and reliable pretreatment approach in gas chromatography-mass spectrometry (GC-MS) was developed for concurrent clean-up of seawater and the concentration of lipophilic polychlorinated biphenyls (PCBs) with 1-8 chlorine atoms based on the combination of $\mathrm{KMnO}_{4}$ oxidation with headspace sampling and solid-phase microextraction (SPME). Factors affecting the extraction process were studied using a multivariable approach. Under optimum conditions such as PDMS $7 \mu \mathrm{m}$ of fiber, $78^{\circ} \mathrm{C}$ of extraction temperature, $33 \mathrm{~min}$ of extraction time, $8 \mathrm{~mL}$ of volume, the limits of detection ranged from 0.3 to $7.5 \mathrm{ng} \mathrm{L}^{-1}$ and precisions were between 3.9 and 9.9\% at spiked $0.05 \mu \mathrm{g} \mathrm{L}^{-1} \mathrm{PCBs}$. Humic acids in seawater exhibited remarkably negative effects; recoveries of PCBs were significantly improved, especially for more lipophilic CB171 and CB201 from $35 \%$ and $49 \%$ to $78 \%$ and $89 \%$, respectively, after $\mathrm{KMnO}_{4}$ pretreating seawater samples at $\mathrm{pH}$ 6. The developed method was demonstrated to be simple, rapid, reliable and applicable for determining different PCBs in seawater containing large amounts of humic substances.

Keywords: polychlorinated biphenyls, headspace solid-phase microextraction, humic substances, experimental design, gas chromatography-mass spectrometry, seawater

\footnotetext{
*e-mail: 1xchen@yic.ac.cn, xlssong@yeah.net

\# Equally contributed to this work
} 


\section{Introduction}

Polychlorinated biphenyls (PCBs) constitute ubiquitous persistent environmental pollutants of great concern owing to their high toxicity and thereby potential risks for ecosystems and human health..$^{1-4}$ However, concentration levels of PCBs in contaminated environment are typically low in complex matrices. ${ }^{5,6}$ Proper sampling and enrichment methods have to be employed to recover sufficient targeted compounds from suspended particulate matter or water phase. ${ }^{7}$ This has promoted rapid developments in sample preparation and chromatographic techniques in the analysis of PCBs. ${ }^{8,9}$

Extraction and preconcentration techniques, such as liquid-liquid extraction (LLE), solid-phase extraction (SPE) and solid-phase microextraction (SPME), have been widely used to determine PCBs. ${ }^{1,10,11}$ LLE and SPE are mainly used, but they have some fundamental limitations. LLE is a laborious, time consuming process and usually requires large amounts of high-purity and toxic solvents. ${ }^{10} \mathrm{SPE}$ is usually faster and consumes less organic solvents than LLE, however, for extraction from high volumes of water samples, the entire analysis of SPE might be lengthy and expensive because of a series of stages..$^{11,12}$ Thus, a relatively simple, rapid, cost-effective, and virtually solvent-free sample preparation method, SPME, has been greatly developed and applied to the determination of PCBs in different matrices, e.g., soil, sediments, water, urine and milk. ${ }^{13-18}$ As for water samples, humic substances are major components of dissolved organic matter (DOM) $)^{5,19}$ and aquatic humic substances have been excellently characterized. ${ }^{20}$ Humic acids significantly reduce the retention of $\mathrm{PCBs}$ and might cause insufficient recoveries attained. ${ }^{14,20,21}$ Coupling of SPME with non-contact (between probe and samples) headspace sampling could greatly reduce matrix interferences for volatile compounds. ${ }^{22-24}$ To quickly and reliably attain the best headspace SPME efficiency, various types experimental designs have been employed, ${ }^{25-27}$ which assisted to optimizing the extraction conditions from a small number of experiments. ${ }^{25-28}$ Moreover, headspace SPME allows using aggressive treatments to reduce their affinity with the sample matrix, and therefore further increases extraction yield. ${ }^{29,30}$

In this work, the feasibility of combining $\mathrm{KMnO}_{4}$ strong oxidation and headspace SPME was demonstrated for pretreating seawater matrices containing numerous humic substances, followed by simultaneous identification and quantification of eight congeners of PCBs using gas chromatography-mass spectrometry (GC-MS). Key parameters affecting headspace SPME efficiency of trace PCBs in aqueous solutions were thoroughly evaluated, such as extraction fiber, extraction temperature, extraction solution volume, humic substance level, sample treatment modes and so on. During the optimization process, a factorial design was run to simultaneously study the influences of main parameters. The developed method was validated and successfully applied to analyze several PCBs in seawater samples.

\section{Experimental}

\section{Chemicals and reagents}

Individual standards of poly- CB1, CB5, CB29, CB47, CB98, CB154, CB171 and CB201 (IUPAC nomenclature) at $500 \mu \mathrm{g} \mathrm{L}^{-1}$ in hexane were purchased from Supelco (Bellefonte, PA, USA). Their physicochemical property parameters are listed in Table $1 .^{31,32}$ Analytical grade $\mathrm{KMnO}_{4}, \mathrm{~K}_{2} \mathrm{CrO}_{4}$, concentrated $\mathrm{H}_{2} \mathrm{SO}_{4}(98 \%)$, potassium hydrogen phthalate (KHP), $\mathrm{HCl}(38 \%)$ and $\mathrm{H}_{2} \mathrm{O}_{2}(30 \%)$ were all acquired from Shanghai Sinopharm Chemical Reagent Company (Shanghai, China). HPLC grade methanol $(\mathrm{MeOH})$ was obtained from Merck (Mollet del Vallés, Barcelona, Spain). Technical grade humic substances namely humic acids in the form of salt were supplied from Tianjin Chemical Research Institute (Tianjin,

Table 1. Physicochemical property parameters of PCBs

\begin{tabular}{|c|c|c|c|c|c|}
\hline IUPAC N. & Congeners & $t_{R}{ }^{a} / \min$ & Qualifiers $(m / z)$ & $\begin{array}{l}\text { Henry coefficients }{ }^{31}-\mathrm{H} \\
\quad\left(\mathrm{Pa} \mathrm{m}^{3} \mathrm{~mol}^{-1}\right)\end{array}$ & $\log \mathrm{K}_{\mathrm{ow}}{ }^{31,32}$ \\
\hline $\mathrm{CB} 1$ & 2-Chlorobiphenyl & 6.5 & $\underline{188}^{\mathrm{b}}, 152$ & $\geq 42.56$ & 4.56 \\
\hline CB5 & 2,3-Dichlorobiphenyl & 8.94 & $\underline{222}, 152$ & $\geq 17.0$ & 5.15 \\
\hline CB29 & 2,4,5-Trichlorobiphenyl & 11.26 & $\underline{256}, 258,186$ & $\geq 24.29$ & 5.77 \\
\hline CB47 & 2,2', 4,4'-Tetrachlorobiphenyl & 13.23 & $\underline{292}, 220,290$ & $\geq 17.2$ & 6.26 \\
\hline CB98 & 2,2',3’,4,6-Pentachlorobiphenyl & 15.11 & $\underline{326}, 324,328$ & $\geq 24.8$ & $>6.2$ \\
\hline CB154 & 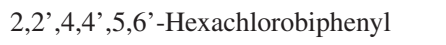 & 17.39 & $\underline{360}, 362,290$ & $\geq 11.9$ & $>6.7$ \\
\hline CB171 & $2,2^{\prime}, 3,3^{\prime}, 4,4^{\prime}, 6-$ Heptachlorobiphenyl & 21.26 & $\underline{394}, 396,324$ & 5.40 & 7.44 \\
\hline CB201 & 2,2',3,3',4,5',6,6'-Octachlorobiphenyl & 21.44 & $\underline{430}, 428,358$ & 38.08 & 8.42 \\
\hline
\end{tabular}




China), which were dissolved in water and centrifuged at $2500 \mathrm{rpm}$ for $30 \mathrm{~min}$ to remove insoluble parts of the technical grade product. Then humic acids at $14 \mathrm{mg} \mathrm{L}^{-1}$ were spiked into seawater samples for use.

\section{Preparation of standards and seawater samples}

Mixed standard stock solutions of the eight PCBs were prepared by successive dilutions with $\mathrm{MeOH}$. Working solutions were prepared by subsequently successive dilutions according to Seawater Preparation Manual written by Subow's Recipe. ${ }^{33}$ Both stock and working solutions were stored at $4{ }^{\circ} \mathrm{C}$. Manual SPME holders and commercially available fiber coatings including polydimethylsiloxane (PDMS) of $100 \mu \mathrm{m}$ and $7 \mu \mathrm{m}$ (bonded), and carbowax/ divinylbenzene (CW/DVB) (65 $\mu \mathrm{m}$, bonded) were obtained from Supelco (Bellefonte, PA, USA). Prior to use, fibers were conditioned in a helium atmosphere according to the manufacturer's instructions. PDMS fiber withstood nearly 100 extraction runs in the headspace mode under normal limits. Highly purified (HPLC-grade) water was obtained by ultra filtration of deionized water with a Milli-Q system (Millipore, Bedford, MA, USA). All analyses were performed in $22 \mathrm{~mL}$ glass SPME vials, and the solutions were stirred with a thermostatic magnetic stirrer (Shanghai Laboratory Instrument Works Co., Ltd. Shanghai, China) using PTFE-coated magnetic stir bars $(10 \mathrm{~mm} \times 3 \mathrm{~mm}$ O.D. $)$.

Surface seawater samples were collected into amber glass containers free of air bubbles, and immediately stored at $4{ }^{\circ} \mathrm{C}$. The samples were filtered through $0.45 \mu \mathrm{m}$ pore size membrane filters (Phenomenex) and analyzed within $24 \mathrm{~h}$. The dissolved total organic carbon (TOC) samples were analyzed by using a TOC- $\mathrm{V}_{\mathrm{CPH}}$ analyzer (Shimadzu, Japan). The samples were acidified with $2 \mathrm{~mol} \mathrm{~L}^{-1} \mathrm{HCl}$ $(\mathrm{pH}<2)$ to remove the inorganic carbonate, then purged with high purity $\mathrm{O}_{2}(99.999 \%)$ for $5 \mathrm{~min}$ to remove the $\mathrm{CO}_{2}$. Then $100 \mu \mathrm{L}$ of the sample was injected into the quartz combustion tube to combust at $680{ }^{\circ} \mathrm{C}$ using platinum coated aluminum beads as catalyst. The samples were then cooled and the chlorine was removed with a halogen scrubber. Finally, the samples were measured in the nondispersive infrared (NDIR) detector (Apollo Electronics Co., Ltd, Shenzhen, China). The calibration curve was done with KHP in water ( 6 concentration levels). The coefficient variation was less than $2 \%(\mathrm{n}=3)$ and the water as reference was 3-7 $\mu \mathrm{MC}$ (i.e., TOC in the water as reference was 3-7 $\mu \mathrm{g} \mathrm{L}^{-1}$ ). As a result, TOC was calculated at $1.23 \mathrm{mg} \mathrm{L}^{-1}$ in the seawater samples.

The studied surface seawater samples were collected from six sampling sites, respectively, including Shilaoren Beach, Zhanqiao Pier Beach and Zhanshan Beach, all in
Qingdao (Qingdao, China), and Laishan Beach, Moon Bay Beach and Golden Sands Beach, all in Yantai (Yantai, China). Three replicates were carried out and finally the results were averaged.

\section{Headspace SPME procedure}

Eight milliliter $(8 \mathrm{~mL})$ seawater samples spiked with $1 \mu \mathrm{g} \mathrm{L} \mathrm{L}^{-1}$ of PCB standard mixtures and a PTFE-coated magnetic stir bar were put into a $22 \mathrm{~mL}$ SPME vial with a PTFE septum and acidified to $\mathrm{pH} \leq 1$. Then $0.01 \mathrm{~mol} \mathrm{~L}^{-1}$ $\mathrm{KMnO}_{4}$ was added dropwise until a persistent violet solution was observed. The solution was stirred for 10 min, followed by the adding of $\mathrm{H}_{2} \mathrm{O}_{2}(10 \%)$ to form a colorless solution. After adjusting the solution acidity to approximately $\mathrm{pH} 6$, the vial was sealed.

The solution was stirred with a magnetic hot stirrer $\left(78^{\circ} \mathrm{C}\right.$ ) at $800 \mathrm{rpm}$ for $5 \mathrm{~min}$. Then the SPME needle was inserted into the sample vial and the fiber was exposed in the headspace above sample for $33 \mathrm{~min}$. After the extraction, the fiber was retracted into the needle which was removed from the septum and then immediately inserted into the GC injection port. Desorption time was set at $5 \mathrm{~min}$ to avoid a possible carryover effect. Desorption temperatures were set at $260{ }^{\circ} \mathrm{C}$ for CW/DVB, and $300{ }^{\circ} \mathrm{C}$ for PDMS. The vials were immediately sealed with hole-caps and PTFE/silicone septa for GC-MS analysis.

\section{GC-MS analysis}

GC-MS analysis was carried out by using GC-MSQP2010 plus with GC-MS solution software-based data handling (Shimadzu, Japan). QP2010 gas chromatograph coupled with a quadrupole mass spectrometer was operated in the electron ionization mode at $70 \mathrm{eV}$ and mass spectra were acquired with a selected ion-monitoring (SIM) mode. An Rtx-5MS $(30 \mathrm{~m} \times 0.25 \mathrm{~mm} \times 0.25 \mu \mathrm{m}$ film thickness) column (Shimadzu, Japan) was used. The GC oven temperature was programmed from $80{ }^{\circ} \mathrm{C}$ (hold for $2 \mathrm{~min}$ ) to $150{ }^{\circ} \mathrm{C}$ (hold for $3 \mathrm{~min}$ ) at $20^{\circ} \mathrm{C} \mathrm{min}^{-1}$, and was increased to $280{ }^{\circ} \mathrm{C}$ (hold for $5 \mathrm{~min}$ ) at $8{ }^{\circ} \mathrm{C} \mathrm{min}{ }^{-1}$. The injector temperature was held at $300^{\circ} \mathrm{C}$, and the injection was performed in a splitless mode (5 min). Helium (purity 99.999\%) was employed as carrier gas at constant column flow of $1 \mathrm{~mL} \mathrm{~min}{ }^{-1}$. The chromatographic run was completed in $23 \mathrm{~min}$. A solvent delay of $4.0 \mathrm{~min}$ was set to protect the filament from oxidation.

Mass spectra were obtained by acquiring data from $\mathrm{m} / \mathrm{z}$ 50-500. Qualitative and quantitative analysis was completed by using the quantifiers coupled with other characteristic ions as qualifiers (Table 1). 


\section{Results and Discussion}

\section{Headspace SPME condition optimization}

Multivariate optimization of selected working conditions for headspace SPME preparation and GC-MS determination were very important for the analysis of those PCBs at low concentrations in water. ${ }^{34}$ As seen from Table 1 , different numbers of chloro substituents of the eight congeners lead to different degrees of volatility and lipophilicity, namely, volatile or semi-volatile PCBs containing 1-6 chlorine atoms and low volatile and more lipophilic PCBs with 7 or 8 ones.

\section{Fiber evaluation}

Fiber coating type largely affects the recoveries of analytes. Many types of commercial fibers are available for determining PCBs. ${ }^{14}$ In this study, three commercial fibers (PDMS of $100 \mu \mathrm{m}$ and $7 \mu \mathrm{m}$, and CW/DVB) were chosen for evaluation. Figure 1 shows the relative extraction efficiencies of PCBs (expressed by peak area of each compound). The semi-polar CW/DVB (bonded) fiber presented remarkably elevated extraction efficiency for the most volatile and polar CBs (1, 5 and 29). The non-polar PDMS fiber of $100 \mu \mathrm{m}$ displayed a slightly higher extraction capacity for CB98 than that of $7 \mu \mathrm{m}$. The highest extraction efficiencies were attained by using the non-polar PDMS of $7 \mu \mathrm{m}$ bonded fiber for more liposoluble CBs $(47,154,171$ and 201) due to the strong interactions between PDMS and

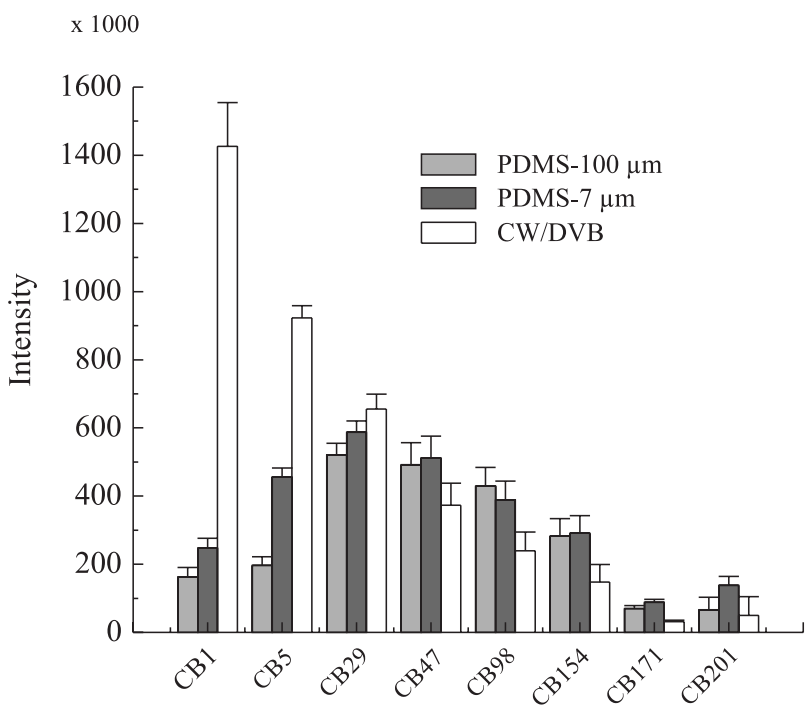

Figure 1. Headspace SPME efficiency obtained by using three different commercial fibers. Responses are the mean values for each fiber expressed as area counts, $\mathrm{n}=80$. Samples were maintained at $80^{\circ} \mathrm{C}$ without the addition of humic substances, magnetically stirring at $800 \mathrm{rpm}$ during extraction. These SPME parameters were optimized using $8 \mathrm{~mL}$ of manual seawater samples spiked with the eight PCBs individual at $1.0 \mu \mathrm{g} \mathrm{L} \mathrm{L}^{-1}$ for each analysis.
CBs. Moreover, the thinner coating of PDMS speeded up mass transfer and shortened equilibrium time. Thus, also as a compromise for all the eight PCBs, the PDMS of $7 \mu \mathrm{m}$ fiber was chosen for further study.

\section{Factorial experimental design}

A factorial design was run to simultaneously study the influences of main factors on micro-extraction process. The factors and levels included in the design were as follows: A, extraction temperature $\left(60\right.$ and $\left.80^{\circ} \mathrm{C}\right)$; B, humic acid level (0 and $14 \mathrm{mg} \mathrm{L}^{-1}$ ); C, extraction time (30 and $40 \mathrm{~min}$ ); D, salinity (30 and 50\%); and E, extraction solution volume ( 5 and $8 \mathrm{~mL}$ ). Figure 2 shows the Pareto Charts.

As shown in Figure 2, extraction temperature was the most influential factor for the extraction of most PCBs. Extraction temperatures had negative effects on CBs (1, 5 and 29); this process could be explained by the slow diffusion of PCBs from sample to headspace phase, where excess PCBs present were to be sorbed on the SPME fiber. ${ }^{35}$ This process differed for each PCB depending on difference in polarity, possible interaction with matrix components or volatility. Temperatures higher than $75^{\circ} \mathrm{C}$ displayed positive effects on several $\mathrm{CBs}$. At a higher temperature $\left(80^{\circ} \mathrm{C}\right)$, a marked decrease in the response for all the CBs was observed, possibly due to the displacement of equilibrium between fiber and headspace to the vapor phase, decreasing retention of compounds on the fiber surface. Therefore, $78^{\circ} \mathrm{C}$ was selected.

The extraction time was also significant for most of the compounds. For CBs (1, 5 and 29), the negative effects played a relatively important role compared to that of the other four factors, while for other CBs, it was clear that the time factor was slightly significant (Figure 2). All the PCBs could be adsorbed into the stationary phase of the fiber coating, but the adsorption equilibrium time was different. Obviously, they increased with the decrease in the volatility of the PCBs. The limited stability of these 8 congeners was confirmed when long pre-heating periods were investigated. Very likely, the PCBs with a low degree of chlorination might also suffer a partial degradation when exposed, during prolonged time, to the strong oxidant conditions. The use of short equilibration time was also favorable to minimize the potential degradation of the PCBs. ${ }^{14}$ Thus, the extraction time was finally set at $33 \mathrm{~min}$.

The salting-out effect was not significant for all the compounds except CB201. As can be seen in Figure 2, the addition of salt was indicated to have only a very slight effect on the extraction of the seven PCBs. In case of CB201, the salinity factor predominated for extraction efficiency with negative effects. Such a decrease of 

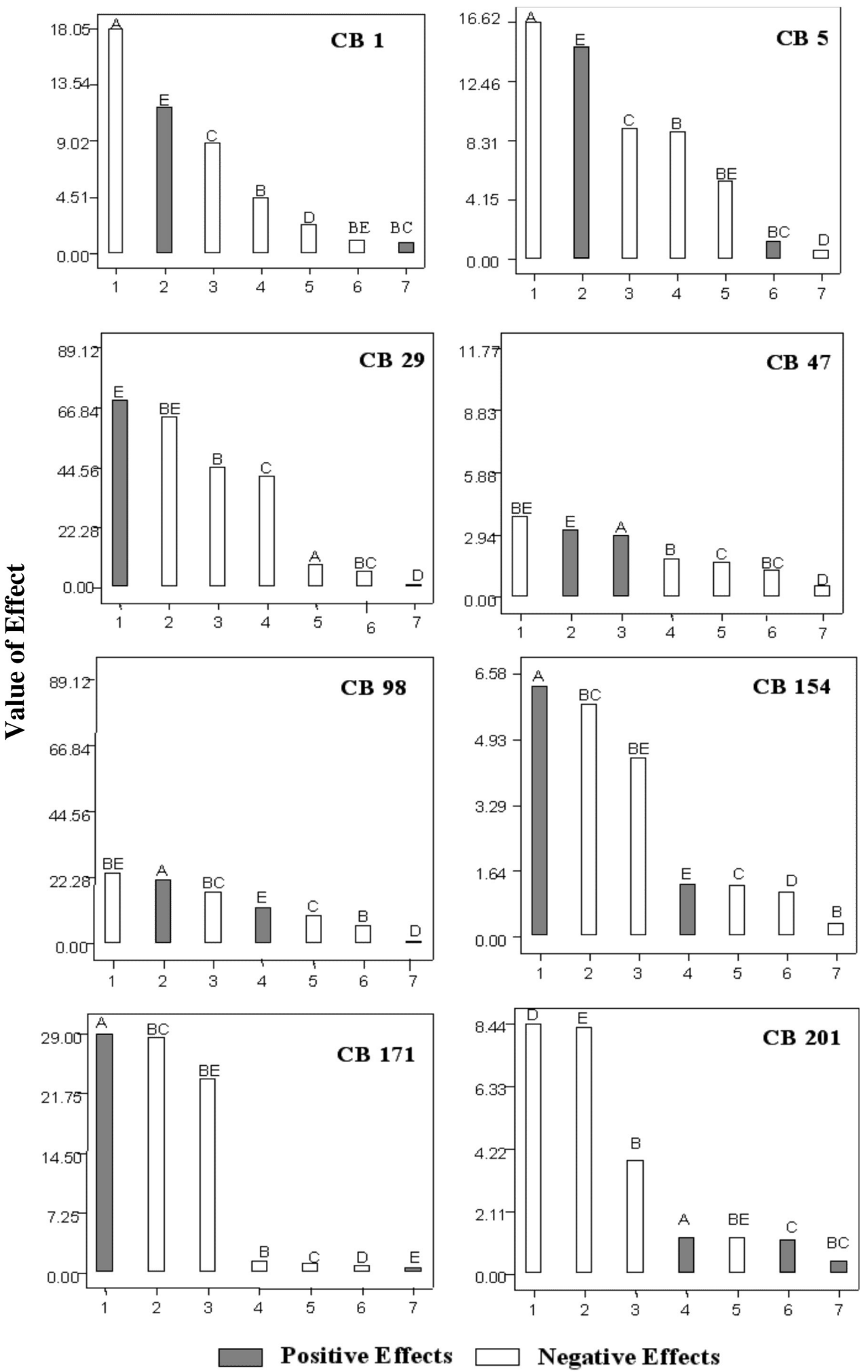

\section{Rank}

Figure 2. Standardized Pareto charts for the main effects and interactions. A: Temperature; B: humic acid; C: exaction time; D: salinity; and E: extraction solution volume. Factors and interactions that produced the lowest effects on the results obtained for each PCB have been removed except for the factor of humic acids. The length of each bar in the graphs is proportional to the absolute value of its associated standardized effect. The effects are displayed in decreasing order of importance, which assists to more easily identify the most important factors and the main effects. 
extraction efficiency for high hydrophobic PCB might result from the increase of viscosity with the addition of salt, slowing down the extraction kinetics of the compound. ${ }^{36}$ Therefore, for less volatile PCBs, it proved that removing the salts from seawater samples was very important.

As for the humic substance factor shown in Figure 2, extraction efficiencies for all the PCBs decreased with the concentration increasing of humic acids. The best results were attained at a very lower level or none of humic acids, meaning their negative effects were unavoidable during sampling seawater containing large amounts of humic substances. It can be attributed in part to the adsorption characteristics and binding phenomena of humic acids. Humic acids may affect the partition or adsorption processes of PCBs, since the association of PCBs with humic acids can lead to enhanced water solubility of the PCBs. ${ }^{37}$ So, humic substances played a significantly negative role in extraction efficiency and their removal or decomposition became very imperative.

The effect of extraction solution volume on the response was also evaluated. As can be seen in Figure 2, the important variable presented positive influence for most congeners of the PCBs. Except for CB201, it was easily saturated into the fiber coating because of its smaller adsorption capacity. Since most compounds showed the higher extraction efficiency at $8 \mathrm{~mL}$ spiked samples volumes, it was selected. Higher volumes were not used to avoid the partial immersion of the fiber.

Regarding factor interactions, the most interesting one was the interaction between humic acids and extraction solution volume (BE), shown in Pareto Charts of Figure 2, indicating significant for most of the PCBs. The estimated response surfaces for the two factors were shown in Figure 3. A noticeable increase in headspace SPME efficiency was observed at an extraction volume of $8 \mathrm{~mL}$ for most PCBs. The efficiency improved when extraction volume increased with the amounts of humic acids decreasing (except CB201). At $8 \mathrm{~mL}$, the two modes, with/without humic acids, were comparable for most of the analyzed PCBs. However, the fact that CB201 could be efficiently extracted at a lower extraction volume of $5 \mathrm{~mL}$ might appear unexpectedly, since the compound could be considered semi-volatile from the value of its Henry's law constant (Table 1). The same behavior had also been described for other compounds, such as polybrominated biphenyls and polybrominated diphenyl ethers. ${ }^{38,39}$

According to the above factorial design, the possible optimum conditions were obtained as follows: $78{ }^{\circ} \mathrm{C}$ of extraction temperature, $33 \mathrm{~min}$ of extraction time, $8 \mathrm{~mL}$ of extraction solution volume, and removing salts and humic substances from seawater samples.

\section{Effect of desorption temperature}

The desorption temperature $\left(250-310^{\circ} \mathrm{C}\right)$ profile was studied. Peak areas of the PCBs increased with desorption temperature from 250 to $300{ }^{\circ} \mathrm{C}$ and remained constant from 300 to $310{ }^{\circ} \mathrm{C}$. All the $\mathrm{PCB}$ s reached maximum response at $300{ }^{\circ} \mathrm{C}$. The maximum endurable temperature of the $7 \mu \mathrm{m}$ PDMS fiber was $320^{\circ} \mathrm{C}$. Hence, $300{ }^{\circ} \mathrm{C}$ as optimal desorption temperature was selected to avoid damage of the fiber.

The fiber coating indicated a quick adsorptions process. For a routine analysis, it is not necessary to reach complete adsorption equilibrium as long as sufficiently low detection limits were acquired. To prevent possible further damage from overusing the fiber, and thereby to increase its service life, 5 min desorption time was chosen.

\section{Sample treatment}

Several seawater samples from six different beach sites were employed for comparisons of different treatment modes, spiked with the 8 PCBs individual at $0.1 \mu \mathrm{g} \mathrm{\textrm {L } ^ { - 1 }}$ and humic acids at a total concentrations of $14 \mathrm{mg} \mathrm{L}^{-1}$. The results gave identical comparison trends. Take seawater sample from Shilaoren Beach as an example. As shown in Figure 4, the most suitable seawater pretreatment mode prior to the extraction of PCBs was the use of $\mathrm{KMnO}_{4}$. Addition of a small quantity of $\mathrm{KMnO}_{4}$ remarkably improved the headspace SPME efficiency, particularly, for the more volatile PCBs (Figure 4). Perhaps the employment of these strong oxidative conditions reduced the DOM content in the extraction vessel and improved the kinetics and thermodynamics of the headspace SPME. ${ }^{14}$ In some cases strong oxidant treatments by $\mathrm{K}_{2} \mathrm{Cr}_{2} \mathrm{O}_{7}$ resulted in lower extraction recoveries as compared to untreated samples (Figure 4). This may be because the oxidizing potential of chromate is high enough to lead to decompositions of the PCBs. The lower responses for the untreated samples were attributed to the great capability of humic substances to enhance the solubility of the PCBs by adsorbing part of them or blocking the active sites of the adsorbents. ${ }^{40}$ It is very necessary to preventively eliminate humic substances for accurate quantification of PCBs. ${ }^{41}$ However, average responses for all compounds remained unaffected when pre-heating held for 5 min or were not assayed under the selected $\mathrm{KMnO}_{4}$ treatment. It was evident that the oxidative action of $\mathrm{KMnO}_{4}$ was relatively fast for PCBs, resulting in good determination stability. Thus, $\mathrm{KMnO}_{4}$ was chosen for sample clean-up and removal of humic substances.

Also, the influence of $\mathrm{pH}$ value was investigated. As seen in Figure 5, best efficiency was achieved at $\mathrm{pH} 6$, 

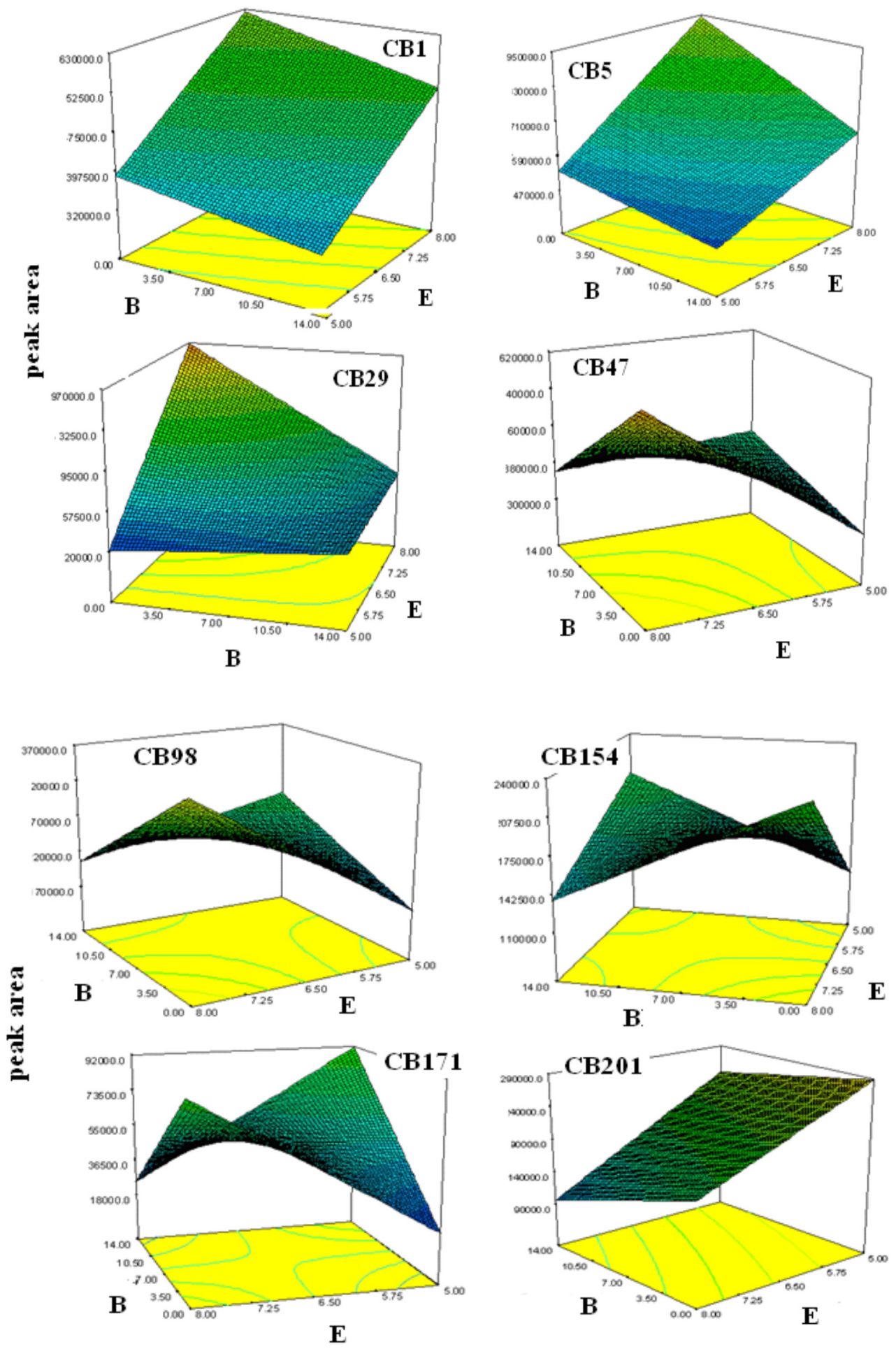

B:Humic acid

\section{E:Volume}

Figure 3. Estimated response surfaces (in area counts) for the factors of humic acid and extraction solution volume for the target PCBs.

which was reduced somewhat at $\mathrm{pH} 10$, while much lower at $\mathrm{pH} 1$. The liposoluble PCBs were volatile or semi-volatile; the acidity-basicity of targeted solution as a significant factor could affect the adsorption amounts of
PCBs. The adverse acid effects on recovering PCBs were more obvious, probably, which would greatly decompose PCBs. Therefore, $\mathrm{pH} 6$ was chosen as the optimal $\mathrm{pH}$ value for PCBs analysis from seawater samples. 


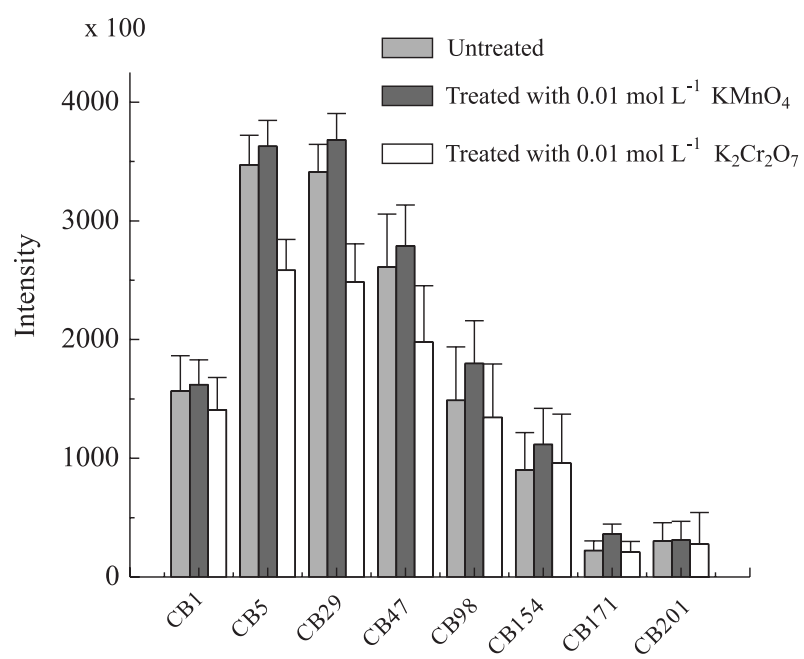

Figure 4. Comparison of the headspace SPME efficiency using three different pre-treatment modes on seawater spiked samples containing PCBs at $0.1 \mu \mathrm{g} \mathrm{L}^{-1}$ and humic acids at a total concentration of $14 \mathrm{mg} \mathrm{L}^{-1}$ (responses are the mean values for each mode expressed as area counts, $\mathrm{n}=3$ replicates).

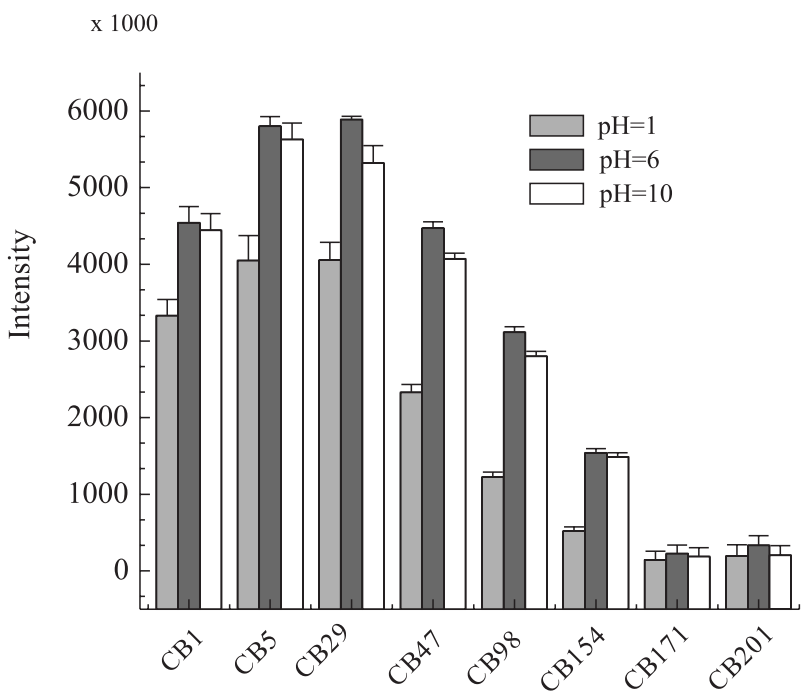

Figure 5. Headspace SPME efficiency at three different $\mathrm{pH}$ values for seawater spiked samples containing PCBs at $1.0 \mu \mathrm{g} \mathrm{L}^{-1}$ and humic acids at a total concentration of $14 \mathrm{mg} \mathrm{L}^{-1}$ (responses are the mean values for each mode expressed as area counts, $n=3$ replicates).

\section{Method performance}

The linearity of the developed method was evaluated using fractions of seawater spiked with increasing concentrations of the individual PCBs at five different concentration levels from $0.01-1.2 \mu \mathrm{g} \mathrm{L}^{-1}$ for each congener except for CB171 and CB201 within 0.05-1.2 $\mu \mathrm{g} \mathrm{L}^{-1}$ (Table 2). Correlation coefficients of the obtained curves ranged from 0.974 to 0.998 showing an acceptable linearity within this interval of concentrations (Table 2). Carry-over effects were investigated by desorbing each $7 \mu \mathrm{m}$ PDMS fiber twice, after being exposed to the seawater sample. When desorption conditions reported were employed, none of the considered PCBs were observed in the second injection with the exception of CB171 and CB201, which had only less than $3 \%$ residual quantities (data not shown). Precision was estimated by processing samples spiked at two levels $\left(0.05\right.$ and $\left.0.2 \mu \mathrm{g} \mathrm{L}^{-1}\right)$. Relative standard deviations (RSD) from 3.9 to $15 \%$ were obtained. Limits of detection (LODs) of the method, defined for a signal to noise $(\mathrm{S} / \mathrm{N})$ ratio of 3, were comprised between 0.3-7.5 $\mathrm{ng} \mathrm{L}^{-1}$ (Table 2). In spite of strong oxidative conditions of $\mathrm{KMnO}_{4}$ in the SPME vessel for the removal of humic substances, PDMS fibers were used for around 70 extractions without noticeable changes in their efficiencies.

\section{Seawater sample analysis}

To further demonstrate the feasibility of the developed method, it was applied to six surface seawater samples. The quantities of PCBs were calculated by the external standard method from an $8 \mathrm{~mL}$ seawater sample. It was observed that there was the similar detection result trends in spite of different values obtained from different sample matrices (Table 3). The endogenous PCBs in the seawater matrices were detected at higher levels when treated with $\mathrm{KMnO}_{4}$ than without treatment; CB5 and CB201 were at too low levels to detect in all the samples; CB29 was not found in

Table 2. Analytical performances of PCBs obtained under the optimized headspace SPME conditions for spiked samples

\begin{tabular}{|c|c|c|c|c|c|}
\hline \multirow{2}{*}{$\mathrm{CB}$} & \multirow{2}{*}{ Linear range / $\left(\mu \mathrm{g} \mathrm{L}^{-1}\right)$} & \multirow{2}{*}{ Correlation coefficient (R) } & \multicolumn{2}{|c|}{$\operatorname{RSD}(\%, \mathrm{n}=5)$} & \multirow{2}{*}{$\mathrm{LOD} /\left(\mathrm{ng} \mathrm{L}^{-1}\right)$} \\
\hline & & & Added $0.05 \mu \mathrm{g} \mathrm{L}^{-1}$ & Added $0.2 \mu \mathrm{g} \mathrm{L}^{-1}$ & \\
\hline 1 & $0.01-1.2$ & 0.991 & 4.7 & 6.5 & 0.3 \\
\hline 5 & $0.01-1.2$ & 0.995 & 6.0 & 4.3 & 4.0 \\
\hline 29 & $0.01-1.2$ & 0.988 & 4.0 & 15.0 & 1.3 \\
\hline 47 & $0.01-1.2$ & 0.978 & 3.9 & 11.5 & 2.9 \\
\hline 98 & $0.01-1.2$ & 0.998 & 9.9 & 7.3 & 4.2 \\
\hline 154 & $0.01-1.2$ & 0.974 & 9.4 & 5.3 & 5.5 \\
\hline 171 & $0.05-1.2$ & 0.986 & 7.7 & 8.5 & 6.4 \\
\hline 201 & $0.05-1.2$ & 0.977 & 8.5 & 12.8 & 7.5 \\
\hline
\end{tabular}


Table 3. Contents and recoveries of PCBs in 6 natural surface seawater samples determined by headspace SPME-GC-MS

\begin{tabular}{|c|c|c|c|c|c|c|c|c|c|c|}
\hline Source & Item & Modes & 1 & 5 & 29 & 47 & 98 & 154 & 171 & 201 \\
\hline \multirow{4}{*}{$\begin{array}{l}\text { Shilaoren } \\
\text { Beach }\end{array}$} & \multirow[t]{2}{*}{ Found / $\left(\mathrm{ng} \mathrm{L}^{-1}\right)$} & Untreated & $3.2 \pm 0.23^{\mathrm{a}}$ & $\mathrm{ND}^{\mathrm{b}}$ & $3.8 \pm 0.18$ & $6.7 \pm 0.15$ & $7.1 \pm 0.38$ & $7.7 \pm 0.39$ & $9.1 \pm 0.45$ & ND \\
\hline & & Treated & $7.1 \pm 0.47$ & ND & $4.4 \pm 0.39$ & $7.7 \pm 0.39$ & $8.2 \pm 0.46$ & $9.9 \pm 0.42$ & $12.6 \pm 0.77$ & ND \\
\hline & \multirow[t]{2}{*}{ Recovery / \% } & Untreated & $92 \pm 1.0$ & $93 \pm 2.2$ & $91 \pm 1.5$ & $76 \pm 1.5$ & $65 \pm 2.6$ & $71 \pm 4.2$ & $36 \pm 7.6$ & $49 \pm 4.2$ \\
\hline & & Treated & $95 \pm 1.5$ & $99 \pm 1.6$ & $97 \pm 0.8$ & $87 \pm 2.0$ & $76 \pm 1.5$ & $94 \pm 2.5$ & $69 \pm 2.8$ & $79 \pm 4.2$ \\
\hline \multirow{4}{*}{$\begin{array}{l}\text { Zhanqiao } \\
\text { Pier Beach }\end{array}$} & \multirow[t]{2}{*}{ Found / $\left(\mathrm{ng} \mathrm{L}^{-1}\right)$} & Untreated & $4.1 \pm 0.34$ & ND & $4.8 \pm 0.25$ & $5.6 \pm 0.35$ & $6.5 \pm 0.32$ & $8.7 \pm 0.36$ & $9.6 \pm 0.41$ & ND \\
\hline & & Treated & $8.3 \pm 0.55$ & ND & $5.6 \pm 0.41$ & $6.7 \pm 0.28$ & $9.2 \pm 0.51$ & $9.6 \pm 0.51$ & $11.8 \pm 0.84$ & ND \\
\hline & \multirow[t]{2}{*}{ Recovery / \% } & Untreated & $93 \pm 2.3$ & $90 \pm 1.6$ & $92 \pm 2.6$ & $78 \pm 2.5$ & $68 \pm 3.3$ & $81 \pm 5.2$ & $38 \pm 8.4$ & $56 \pm 5.2$ \\
\hline & & Treated & $97 \pm 2.4$ & $98 \pm 1.3$ & $99 \pm 1.28$ & $88 \pm 2.6$ & $79 \pm 2.5$ & $96 \pm 3.7$ & $78 \pm 2.9$ & $84 \pm 3.2$ \\
\hline \multirow{4}{*}{$\begin{array}{l}\text { Zhanshan } \\
\text { Beach }\end{array}$} & \multirow[t]{2}{*}{ Found / $\left(\mathrm{ng} \mathrm{L}^{-1}\right)$} & Untreated & $2.5 \pm 0.43$ & ND & $2.7 \pm 0.16$ & $5.7 \pm 0.23$ & $7.3 \pm 0.48$ & $6.7 \pm 0.27$ & $8.6 \pm 0.53$ & ND \\
\hline & & Treated & $5.3 \pm 0.32$ & ND & $3.8 \pm 0.22$ & $8.3 \pm 0.42$ & $9.2 \pm 0.55$ & $8.5 \pm 0.41$ & $14.9 \pm 0.91$ & ND \\
\hline & \multirow[t]{2}{*}{ Recovery / \% } & Untreated & $90 \pm 1.9$ & $90 \pm 3.2$ & $90 \pm 1.5$ & $78 \pm 2.1$ & $70 \pm 3.6$ & $72 \pm 4.3$ & $45 \pm 5.8$ & $55 \pm 5.1$ \\
\hline & & Treated & $92 \pm 2.6$ & $95 \pm 1.5$ & $95 \pm 1.3$ & $89 \pm 2.3$ & $81 \pm 2.5$ & $95 \pm 2.7$ & $79 \pm 3.2$ & $89 \pm 5.7$ \\
\hline \multirow{4}{*}{$\begin{array}{l}\text { Laishan } \\
\text { Beach }\end{array}$} & \multirow[t]{2}{*}{ Found / (ng L $\left.{ }^{-1}\right)$} & Untreated & $2.1 \pm 0.15$ & ND & ND & $5.8 \pm 0.31$ & $6.5 \pm 0.47$ & $7.5 \pm 0.40$ & $7.8 \pm 0.51$ & ND \\
\hline & & Treated & $6.3 \pm 0.36$ & ND & ND & $7.4 \pm 0.26$ & $7.9 \pm 0.26$ & $9.6 \pm 0.51$ & $10.6 \pm 0.54$ & ND \\
\hline & \multirow[t]{2}{*}{ Recovery / \% } & Untreated & $90 \pm 1.3$ & $90 \pm 2.6$ & $89 \pm 3.4$ & $78 \pm 2.3$ & $72 \pm 2.5$ & $76 \pm 5.2$ & $45 \pm 5.2$ & $50 \pm 5.1$ \\
\hline & & Treated & $95 \pm 1.8$ & $99 \pm 2.5$ & $94 \pm 1.2$ & $90 \pm 2.0$ & $80 \pm 1.8$ & $95 \pm 2.4$ & $70 \pm 2.4$ & $81 \pm 3.6$ \\
\hline \multirow{4}{*}{$\begin{array}{l}\text { Moon Bay } \\
\text { Beach }\end{array}$} & \multirow[t]{2}{*}{ Found / $\left(\mathrm{ng} \mathrm{L}^{-1}\right)$} & Untreated & $2.4 \pm 0.16$ & ND & ND & $4.5 \pm 0.29$ & $6.8 \pm 0.51$ & $6.9 \pm 0.51$ & $8.1 \pm 0.35$ & ND \\
\hline & & Treated & $6.5 \pm 0.51$ & ND & ND & $6.3 \pm 0.44$ & $8.5 \pm 0.55$ & $9.5 \pm 0.54$ & $11.4 \pm 0.69$ & ND \\
\hline & \multirow[t]{2}{*}{ Recovery / \% } & Untreated & $90 \pm 2.1$ & $94 \pm 3.5$ & $90 \pm 2.5$ & $74 \pm 2.5$ & $60 \pm 3.2$ & $70 \pm 3.2$ & $35 \pm 3.2$ & $55 \pm 5.2$ \\
\hline & & Treated & $97 \pm 3.5$ & $97 \pm 2.7$ & $95 \pm 1.8$ & $80 \pm 2.3$ & $75 \pm 2.5$ & $92 \pm 2.1$ & $70 \pm 2.7$ & $86 \pm 5.7$ \\
\hline \multirow{4}{*}{$\begin{array}{l}\text { Golden } \\
\text { Sands } \\
\text { Beach }\end{array}$} & \multirow[t]{2}{*}{ Found / $\left(\mathrm{ng} \mathrm{L}^{-1}\right)$} & Untreated & $5.4 \pm 0.64$ & ND & ND & $5.8 \pm 0.21$ & $7.0 \pm 0.56$ & $7.4 \pm 0.49$ & $9.2 \pm 0.62$ & ND \\
\hline & & Treated & $9.8 \pm 0.75$ & ND & ND & $7.3 \pm 0.26$ & $9.4 \pm 0.66$ & $9.6 \pm 0.52$ & $11.4 \pm 0.81$ & ND \\
\hline & \multirow[t]{2}{*}{ Recovery / \% } & Untreated & $93 \pm 2.2$ & $94 \pm 2.8$ & $90 \pm 3.5$ & $79 \pm 2.3$ & $68 \pm 2.5$ & $70 \pm 4.1$ & $39 \pm 5.6$ & $59 \pm 3.2$ \\
\hline & & Treated & $97 \pm 3.1$ & $97 \pm 2.7$ & $96 \pm 1.8$ & $85 \pm 3.1$ & $79 \pm 1.8$ & $96 \pm 2.7$ & $70 \pm 2.5$ & $86 \pm 5.6$ \\
\hline
\end{tabular}

${ }^{a}$ Averaged from three replicates. ${ }^{b}$ Not detected. ${ }^{c}$ Spiked each congener concentration at $0.1 \mu \mathrm{g} \mathrm{L}{ }^{-1}$.

the three beach sites of Yantai. Recoveries were calculated for the six spiked water samples with $0.1 \mu \mathrm{g} \mathrm{L}^{-1}$ standards, respectively. Possibly due to the interferences of humic substances, poor recoveries for untreated seawater samples were relatively low, especially for CB171 and CB201 with only $35 \%$ and $49 \%$, respectively (Table 3 ).

For the seawater samples treated with $\mathrm{KMnO}_{4}$, the endogenous concentrations of PCBs were more sensitively determined and the recoveries were improved up to $69-99 \%$ (Table 3), which revealed that the strong oxidative activation of $\mathrm{KMnO}_{4}$ reduced the content of humic substances and improved the kinetics and thermodynamics of the headspace SPME and therefore the extraction recoveries. The treated samples presented low DOM content and the recovery values were satisfactory.

\section{Conclusions}

The addition of small amounts of $\mathrm{KMnO}_{4}$ to seawater samples prior to headspace sampling with SPME extraction proved to be an effective, rapid, and convenient sample pretreatment approach to enhance the concentration detection sensitivity of PCBs using GC-MS. And the factorial design accelerated the gains of optimum headspace SPME conditions. The developed method provided acceptable linearity range, precision and LODs at $\mathrm{ng} \mathrm{L}^{-1}$ level. Sample treatment with $\mathrm{KMnO}_{4}$ effectively minimized adverse effects of humic substances and presented high extraction efficiency and recoveries. The use of the headspace SPME device and the $\mathrm{KMnO}_{4}$ treatment would allow the automation of the whole sample preparation step and increase the applicability of the developed method in screening studies. The method could be further improved by including other congeners and/or appropriate internal standards in order to minimize matrix effects during the extraction steps.

\section{Acknowledgments}

This work was financially supported by the National Natural Science Foundation of China ((20975089, 21105117, 20907039), the Department of Science and Technology 
of Shandong Province of China (2010GSF10222), the Natural Science Foundation of Shandong Province of China (Y2007B38, ZR2010BQ027), the Innovation Projects of the Chinese Academy of Sciences (KZCX2EW-206), the Key Laboratory Foundation of Soil and Water Conservation and Environmental Conservation of Shandong Province of China (STKF201010), the Programs of State Key Laboratory of Food Science and Technology of Nanchang University of China (SKLF-KF-201006, SKLF-MB-201005), the Yantai Research and Development Program of China (2010158, 2007323), and the 100 Talents Program of the Chinese Academy of Sciences.

\section{References}

1. Lambropoulou, D. A.; Konstantinou, I. K.; Albanis, T. A.; J. Chromatogr., A 2006, 1124, 97.

2. Liu, S. J.; Zhang, S. P.; Qu, C.; Liu, W.; Du, Y. G.; Sci. Chin. Chem. 2010, 53, 974.

3. Oberson, D; Lafon, D; Arch. Mal. Prof. Environ. 2010, 71, 141.

4. Matsui, T.; Uchimura, T.; Imasaka, T.; Anal. Chim. Acta 2011, 684, 108.

5. Botero, W. G.; de Oliveira, L. C.; Cunha, B. B.; de Oliveira, L. K.; Goveia, D.; Rocha, J. C.; Fraceto, L. F.; Rosa, A. H.; J. Braz. Chem. Soc. 2011, 22, 1103.

6. Wang, Y. H.; Li, Y. Q.; Zhang, J.; Xu, S. F.; Yang, S. G.; Sun, C.; Anal. Chim. Acta 2009, 646, 78.

7. Song, X. L.; Li, J. H.; Liao, C. Y.; Chen, L. X.; Chromatographia 2011, 74, 89.

8. Quintanilla-Lopez, J. E.; Galindo-Iranzo, P.; Gomara, B.; Lebron-Aguilar, R.; J. Chromatogr., A 2010, 1217, 7231.

9. Liu, X. J.; Zhao, A. J.; Zhang, A. N.; Liu, H. Q.; Xiao, W. J.; Wang, C. J.; Wang, X. D.; J. Sep. Sci. 2011, 34, 1084.

10. Toledo, C.; Valle, L.; Narvaez, J.; Richter, P.; J. Braz. Chem. Soc. 2007, 18, 937.

11. Yang, F. X.; Jin, S. W.; Meng, D. Y.; Xu, Y.; Chemosphere 2010, $81,1000$.

12. Li, J. H.; Cai, Z. W.; Xu, S. F.; Liao, C. Y.; Song, X. L.; Chen, L. X.; J. Liq. Chromatogr. Relat. Technol. 2011, 34, 1578.

13. Poli, D.; Caglieri, A.; Goldoni, M.; Castoldi, A. F.; Coccini, T.; Rod, E.; Vitalone, A.; Ceccatelli, S.; Mutti, A.; J. Chromatogr., B: Anal. Technol. Biomed. Life Sci. 2009, 877, 773.

14. Montes, R.; Ramil, M.; Rodriguez, I.; Rubi, E.; Cela, R.; J. Chromatogr., A 2006, 1124, 43.

15. Hawthorne, S. B.; Grabanski, C. B.; Hageman, K. J.; Miller, D. J.; J. Chromatogr., A 1998, 814, 151.

16. Cortazar, E.; Zuloaga, O.; Sanz, J.; Raposo, J. C.; Etxebarria, N.; Fernandez, L. A.; J. Chromatogr., A 2002, 978, 165.

17. Hong, J. E.; Pyo, H.; Park, S. J.; Lee, W.; Anal. Chim. Acta 2005, 539, 55.
18. Kowalski, C. H.; Costa, J. G.; Godoy, H. T.; Augusto, F.; J. Braz. Chem. Soc. 2010, 21, 502.

19. Thurman, E. M. In Organic Geochemistry of Natural Waters; Martinus Nijhoff/Dr WJunk Publishers: Dordrecht, 1985.

20. Rodriguez, F. J.; Nunez, L. A.; Water Environ. J. 2011, 25, 163.

21. Otaka, H.; Shimono, H.; Hashimoto, S.; Anal. Bioanal. Chem. 2004, 378, 1854

22. Ma, J. P.; Lu, W. H.; Li, J. H.; Song, Z. W.; Liu, D. Y.; Chen, L. X.; Anal. Lett. 2011, 44, 1544.

23. Vichi, S.; Castellote, A.; Pizzale, L.; Conte, L. S.; Buxaderas, S.; Lopez-Tamames, E.; J. Chromatogr., A 2003, 983, 19.

24. Ma, J. P.; Xiao, R. H.; Li, J. H.; Li, J.; Shi, B. Z.; Liang, Y. J.; Lu, W. H.; Chen, L. X.; J. Sep. Sci. 2011, 34, 1477.

25. Dron, J; Garcia, R; Millan, E.; J. Chromatogr., A 2002, 963, 259.

26. Larreta, J.; Vallejo, A.; Bilbao, U.; Alonso, A.; Arana, G.; Zuloaga, O.; J. Chromatogr., A 2006, 1136, 1.

27. Liorente, D. D.; Abrodo, P. A.; de la Fuente, F. D.; Alvarez, J. G.; Alvarez, M. D. G.; Gomis, D. B.; J. Sep. Sci. 2011, 34, 1293.

28. Wen, Y. Y.; Li, J. H.; Zhang, W. W.; Chen, L. X.; Electrophoresis 2011, 32, 2131.

29. Llompart, M.; Pazos, M.; Landin, P.; Cela, R.; Anal. Chem. 2001, 73, 5858.

30. Shu, Y. Y.; Wang S. S.; Tardif, M.; Huang, Y. P.; J. Chromatogr., A 2003, $1008,1$.

31. Wang, L. S.; Han, S. K.; Organic Pollution Progress in Chemistry, Chemical Industry Press: Beijing, 1998.

32. Mackay, D.; Shiu, W. Y.; Ma, K. C.; Lee, S. C.; Handbook of Physical-Chemical Properties and Environmental Fate for Organic Chemicals, $2^{\text {nd }}$ ed., Lewis: Boca Raton, 2006.

33. Zhang, Z. B.; Liu, L. S.; Marine Physical Chemistry, Science Press: Beijing, 1989.

34. Mmualefe, L. C.; Torto, N.; Mapil, P. H.; Mbongwe, B.; Microchem. J. 2009, 91, 239.

35. Serrano, E.; Beltrán, J; Hernández, F.; J. Chromatogr., A 2009 , 1216, 127.

36. Quintana, J. B.; Rodil, R.; Muniategui-Lorenzo, S.; LopezMahia, P.; Prada-Rodriguez, D.; J. Chromatogr., A 2007, 1174, 27.

37. Knulst, J. C. C.; Environ. Toxicol. Chem. 1992, 11, 1209.

38. Landin, P.; Lompart, M.; Lourido, M.; Cela, R.; J. MIcrocolumn Sep. 2001, 13, 275.

39. Polo, M.; Gómez-Noya, G.; Quintana, J. B.; Lompart, M.; García-Jares, C. C. R.; Anal. Chem. 2004, 76, 1054.

40. Wu, J. X.; Cao, L.; Wang, H. Z.; Metall. Anal. 2006, $26,1$.

41. Christoforids, A.; Stamatis, N.; Schmieder, K.; Tsachalidis, E.; Chemosphere 2008, 70, 694.

Submitted: September 22, 2010 Published online: November 3, 2011 